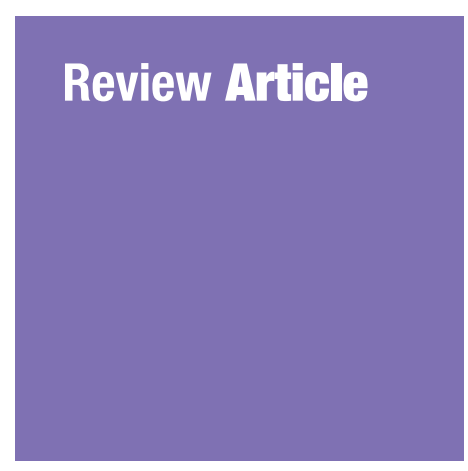

Submitted: $10 \mathrm{Jul} 2018$

Accepted: 19 Nov 2018

Online: 30 Apr 2019

\title{
Dietary Carbohydrate Promotes Cell Survival in Cancer Via the Up-Regulation of Fat Mass and Obesity-Associated Gene Expression Level
}

\author{
Saeid DoAeI ${ }^{1,2,3}$, Maryam GHolamalizadeH ${ }^{1}$, Mohammad \\ Esmaeil AKBARI ${ }^{4}$, Shayan AKBARI ${ }^{5}$, Hyuliya FERADOVA ${ }^{6}$, \\ Ghazaleh RAHIMZADEH $^{7}$, Alireza MOSAVI JARRAHI ${ }^{8}$
}

1 Student Research Committee, Cancer Research Center, Shahid Beheshti University of Medical Sciences, Tehran, Iran

2 Gastrointestinal and Liver Disease Research Center, Guilan University of Medical Sciences, Rasht, Iran

3 Department of Health Education, School of Health, Guilan University of Medical Sciences, Rasht, Iran

4 Cancer Research Center, Shahid Beheshti University of Medical Sciences, Tehran, Iran

5 Department of Nutrition, Iran University of Medical Sciences, Tehran, Iran

6 Department of General Surgery, UMHAT St. Marina, Medical University of Pleven, Bulgaria

7 Institute for Intelligent Systems Research and Innovation (IISRI), Deakin University, Geelong Waurn Ponds, Australia

8 School of Medicine, Shahid Beheshti University of Medical Sciences, Tehran, Iran

To cite this article: Doaei S, Gholamalizadeh M, Akbari ME, Akbari S, Feradova H, Rahimzadeh G, Mosavi Jarrahi A. Dietary carbohydrate promotes cell survival in cancer via the up-regulation of fat mass and obesity-associated gene expression level. Malays J Med Sci. 2019;26(2):8-17. https://doi.org/10.21315/mjms2019.26.2.2

To link to this article: https://doi.org/10.21315/mjms2019.26.2.2

\section{Abstract}

Cancer cells are mainly dependent on glycolysis for their growth and survival. Dietary carbohydrates play a critical role in the growth and proliferation of cancer and a low-carbohydrate diet may help slow down the growth of tumours. However, the exact mechanisms behind this effect are unclear. This review study aimed to investigate the effect of fat mass and obesity-associated (FTO) gene in the association between dietary carbohydrates and cancer. This study was carried out using keywords such as polymorphism and/or cancer and/or dietary carbohydrate and/or FTO gene. PubMed and Science Direct databases were used to collect all related articles published from 1990 to 2018.

Recent studies showed that the level of FTO gene expression in cancer cells is dramatically increased and may play a role in the growth of these cells through the regulation of the cellular metabolic pathways, including the phosphoinositide 3-kinases/protein kinaseB (PI3K/AKT) signaling pathway. Dietary carbohydrate may influence the FTO gene expression by eliminating the inhibitory effect of adenosine monophosphate-activated protein kinase (AMPK) on the FTO gene 
expression. This review summarised what has been recently discovered about the effects of dietary carbohydrate on cancer cells and tried to determine the mediating role of the FTO gene in these effects.

Keywords: cancer, FTO gene, dietary carbohydrate

\section{Introduction}

Recent studies suggested that healthy diet can play a major role in the prevention of cell malignancy, apoptosis of cancer cells and reduced tumour size (1-6). For example, the role of many vitamins and phytochemicals (such as curcumin) in cellular division and apoptosis has been frequently reported (7-9). More recently, the role of macronutrients such as carbohydrate in controlling the growth of cancer cells has attracted the attention of scientists (10). Cancer cells are dependent on their access to glucose for growth and reproduction; controlling blood glucose at an optimal level in cancer patients may be a practical way to avoid increasing the size of a tumour (11). One of the most recommended diets is the ketogenic diet that may be effective in reducing cancer cell growth by reducing the level of glucose availability (12).

Until recently not a lot has been found about the existing mechanisms by which dietary components affect the formation of cancer cells. The results of most studies suggest that some part of this effect may be due to the effects of dietary intake on the expression of some of the genes involved in the cell metabolism and division. The relation between gene variations and risk of cancer is well documented $(13,14)$. Cancer is a genetic disease caused by changes in the genes which have a role in the control of the growth, division and function of our cells (14). When tumour suppressor genes such as breast cancer genes 1 and 2 (BRCA1, BRCA2), and P53 carry a mutation, the cells can grow out of control and may lead to tumour formation (15). Recent studies have focused on the genes that are influenced by the environmental factors like dietary intake. It is assumed that the amount of nutrients available to the cell may modify the level of expression of some genes associated with cell growth and proliferation $(16,17)$. In other words, it is possible that dietary components play a major role in the risk of developing cancer through their effects on the expression of certain genes involved in the growth and proliferation of cancer cells (17). One of the genes that has recently been featured in this context is the fat mass and obesity-associated (FTO) gene (18). The association between the FTO gene and obesity has been confirmed through the study of the FTO gene polymorphisms. People who have the risk allele in the polymorphisms of the FTO gene (e.g. rs9939609 \& rs9930506) have a greater risk of developing obesity (19). The amount of FTO gene expression in various tissues is also linked to body fat percentage and obesity (20). More recently, studies have shown that some of the effects of the FTO gene may be due to the impact of the intron regions of this gene on the expression of other genes, including the iroquois homeobox gene 3 (IRX 3 gene) (21). The interactions between diet and the FTO gene have been recently reported in some studies (22). Considering the role of carbohydrates in cancer cell metabolism, this study aimed to investigate the mediating role of the FTO gene in the effect of dietary carbohydrates on cancer cells. First, we reviewed the role of several diets with different amounts of macronutrients administered to cancer patients. Then, we studied the role of the macronutrients in FTO gene expression. The probable molecular mechanisms of the association between the FTO gene and cancer development were also reviewed.

\section{Methodology}

PubMed, PsycInfo and the Cochrane databases were searched to identify articles published in relevant fields. Appropriate keywords including carbohydrate, diet, FTO expression, FTO genotype, cancer, cell and metabolism (alone and together) were used to collect the papers. All articles published in English from June 1990 to July 2018 were studied. Of the total 180 articles, 109 articles were excluded because they failed to address the role of the FTO gene in breast cancer and/ or obesity and 63 articles for lack of sufficient information on the mechanism of the effects of FTO gene on the breast cancer and obesity. Finally, eight articles were included. Of these studies, five studies were on the relationship between dietary carbohydrate and cancer, and five were related to the molecular mechanisms of dietary carbohydrate on FTO gene. 


\section{Dietary Carbohydrate and Cancer}

Unlike normal cells, most malignant cells are dependent on the availability of sugar in the blood constantly for energy supply and to meet demands for their metabolism. These cells are unable to metabolise fatty acids and ketone bodies due to mitochondrial dysfunction. Previous studies reported the benefits of a lowcarbohydrate diets on human body weight and general health (23). Ho et al. compared the effects of a low-carbohydrate diet compared to a western diet on tumour growth in mice (24). They first designed a low carbohydrate diet containing $8 \%$ carbohydrate (\% of total calories), $23 \%$ fat and $69 \%$ protein versus a western diet (55\% carbohydrate, $23 \%$ protein, $22 \%$ fat). The results showed that the growth of the cancer cells in low-carbohydrate and highprotein group was slower than their growth in a high-carbohydrate western diet. There were no differences between the weights of the cancerbearing mice in the two groups. In addition, mice with a low-carbohydrate diet had lower levels of blood sugar, insulin and lactate. Only one rat on western diets could have a normal lifespan with cancer-related death, while more than $50 \%$ of the mice with a low-carbohydrate diet had a normal lifespan. It is also suggested that a low-carbohydrate diet possibly slows down the growth of cancer cells by reinforcing the inhibitory effects on the mechanistic target of rapamycin (mTOR) pathway. Taken together, the findings of this study revealed the ability of a low-carbohydrate diet to slow down the development of cancer without any impacts on weight.

Moulton et al. evaluated the effects of two different ratios of carbohydrate and protein in the early development of breast tissue carcinogenesis in an animal study (25). After tumour induction, the mice were exposed to either a low-protein and high-carbohydrate [(LPHC); $15 \%$ and $60 \%$ of energy, respectively] diet or a high-protein and moderatecarbohydrate [(HPMC); $35 \%$ and $40 \%$ of energy, respectively] diet for 10 weeks. The rate of the palpable tumours in the HPMC group compared to the LPHC group was lower and the level of insulin serum in the LPHC group was significantly higher than in the HPMC group. The researchers concluded that a low-carbohydrate diet can help to slow down the growth of breast tumours. The insulin-like growth factor 1 (IGF-1) system was reported as a key regulator of the cancer growth pathway and it seems that the reduction of insulin levels through diet or medication (e.g. metformin) was beneficial in cancer patients (26).

Sieri et al. conducted a cohort study and examined whether the glycemic load (GL) and the glycemic index (GI) are associated with the risk of breast cancer in women (27). A total of 289 patients with breast cancer were followed after 11.5 years. The results showed that the relative risk of the development of cancer with high GI and high GL were 1.57 and 2.53, respectively $(P<0.05)$. The risk of breast cancer was associated with the consumption of carbohydrates with higher $\mathrm{GI}_{\mathrm{s}}$ ( $P$ for trend $<0.001$ ).

The association between hyperglycemia and cancer risk was examined in 33,293 women and 31,304 men in northern Sweden (28). The results showed that the overall risk of cancer in women with the top quartile of fasting blood sugar (FBS) and blood sugar (BS) compared to bottom quartile was 1.75 versus 1.63 . The risks of pancreatic, endometrium, urinary tract pipe and malignant melanoma cancers were associated with high FBS level, with the relative risk of 2.49, $1.86,1.69$, and 2.19 , respectively.

Tan-Shalaby et al. examined the impact of the modified Atkins diet on cancer development. A total of 17 patients with advanced cancer, who had not undergone chemotherapy, were enrolled for the study (29). They received $20 \mathrm{~g}-40 \mathrm{~g}$ of carbohydrates daily for 16 weeks and were assessed every 4 weeks. The results showed that the modified Atkins diet is a safe and practical approach to prevent cancer progression and it can promote the quality of life. The survival time was also improved in some patients with lung cancer and melanoma.

Moreover, the effect of ketogenic diet as a well-known low-carbohydrate diet on tumour growth was investigated and approved in several studies (30-39). Reducing the amount of dietary carbohydrates is reported to suppress-or at least delay-the incidence of cancer and slow down the proliferation of cancer cells (30-34). Carbohydrates can have direct and indirect effects on the proliferation of cancer cells (40). A recent study identified that an increase in ketone bodies after a decrease in insulin and blood glucose had a negative effect on the proliferation of malignant cells in vitro during a calorie-restricted diet (41). It has recently been reported that the dependency of cancer cells on glycolysis (Warburg effect) may have a key role 
in the progression of cancer cells, but is not a cause of it (42). The studies on the mechanism of the effect of carbohydrates on the growth and proliferation of cancer cells reported that high levels of blood glucose and insulin will apply some of their effects through the steady activation of phosphoinositide 3-kinase/protein kinase $\mathrm{B}\left(\mathrm{PI}_{3} \mathrm{~K} / \mathrm{AKT}\right)$ pathway that is involved in cell survival and eventually increase the risk of cancer $(43,44)$. However, the precise mechanism behind these effects of carbohydrate on this metabolic pathway is unclear.

\section{FTO Has a Possible Mediatory Role in the Association between Carbohydrates and Breast Cancer}

FTO gene is known for its role in obesity and diabetes (19). The association between the FTO gene expression and cancer risk was also recently identified (45-47). The FTO gene may exert its effect through different mechanisms. It was reported that the level of FTO gene expression is higher in cancer cells than in normal cells and the cells adjacent to cancer tissue $(45,46)$. Moreover, the polymorphisms in the FTO gene are associated with cancer and may exert their role through their influence on the expression of the effective genes in cancer (47). However, some studies showed that there is no association between the FTO gene polymorphisms and the risk of cancer $(48,49)$. Yang et al. reported that there is no evidence that the gene variants in FTO are associated with a risk of colorectal cancer (49). In another study, the FTO rs11075995 variant risk allele was reported to be associated with breast cancer risk, without adjustment for body mass index (BMI). However, the adjustment to BMI led to the disappearance of this association, indicating that there is no independent association between the FTO polymorphism and the risk of breast cancer (50).

Recent studies on the relationship between the macronutrients intake and the level of FTO gene expression in the hypothalamus identified that dietary carbohydrates can affect the FTO gene expression level. However, the results in this area are contradictory and in some studies carbohydrate intake up-regulated the FTO gene expression, while in other studies it suppressed FTO gene expression (51). It is possible that this effects of dietary carbohydrates may depend on FTO genotype and FTO gene polymorphisms play a role in the association between carbohydrate intake and FTO gene expression (52, 53). Some recent studies showed the impact of carbohydrate intake on the association between FTO and BMI. A cross-sectional study on 4,839 Swedish people showed that the relation between FTO gene polymorphisms and obesity can be seen only in people who have a high rate of fat and low rate of carbohydrate intake (52). However, the results in this area were contradictory. For example, in a study by Qi et al. on 16,094 patients between 1 and 18 years, carbohydrate intake had no effect on the relationship between FTO and BMI (Table 1) (53).

The possible mechanism behind the effect of the FTO gene on cancer risk has been studied recently. The FTO gene may act as a mediator for the phosphorylation of serine in location 473 of the AKT protein and its activation has a key role in the proliferation and differentiation of cells (54). It was assumed that an increase in the FTO gene expression can increase glycolysis in the cancer cells by effect on the PI3K/AKT signaling pathway (55). It was also reported that the $\mathrm{PI}_{3} \mathrm{~K} /$ AKT pathway is a mediator of the association between estrogen and the level of FTO gene expression and subsequent cell survival (56). It seems that the association between the FTO gene and cancer cells is more tangible in hormonedependent cancers (Figure 1).

\section{Conclusion}

Cancer cells are dependent on glycolysis for their growth and proliferation. Dietary carbohydrate is a significant factor and the association between blood glucose levels and cancer is well documented. But the exact mechanisms of this relationship remain unclear. Recent studies showed that dietary macronutrients may have an impact on cancer by altering the expression level of the genes associated with the metabolism of cancer cells (such as FTO). If we could improve the expression levels of the genes involved in growth, metabolism, and the function of cancer cells through changing our diet, we can hope to find a nutritionally applicable solution for the treatment and control of cancer in the future. Further research on the exact mechanism of the influence of FTO gene on the growth and proliferation of cancer cells may clarify the importance of this issue and the possibility of therapeutic use of dietary components in cancer. 
Table 1. Summary of study descriptions

\begin{tabular}{|c|c|c|c|c|}
\hline Reference & Title & Study design & $\begin{array}{l}\text { Examined } \\
\text { components }\end{array}$ & Main finding(s) \\
\hline \multicolumn{5}{|c|}{ Dietary carbohydrate and cancer } \\
\hline Ho et al. (24) & $\begin{array}{l}\text { A low-carbohydrate, high-protein } \\
\text { diet slows tumour growth and } \\
\text { prevents cancer initiation }\end{array}$ & Experimental & $\begin{array}{l}\text { A low-carbohydrate, } \\
\text { high-protein diet vs } \\
\text { a high-carbohydrate, } \\
\text { low-protein diet }\end{array}$ & $\begin{array}{l}\text { The ability of a low } \\
\text { carbohydrate diet to slow } \\
\text { down the development o } \\
\text { cancer without any impact on } \\
\text { weight }\end{array}$ \\
\hline $\begin{array}{l}\text { Moulton et al. } \\
\text { (25) }\end{array}$ & $\begin{array}{l}\text { A HPMC diet fed at discrete meals } \\
\text { reduces early progression of } \\
\text { N-methyl-N-nitrosourea-induced } \\
\text { breast tumourigenesis in rats }\end{array}$ & Experimental & $\begin{array}{l}\text { A low-protein and } \\
\text { high-carbohydrate } \\
\text { diet vs HPMC diet }\end{array}$ & $\begin{array}{l}\text { A low-carbohydrate diet can } \\
\text { help to slow down the growth } \\
\text { of breast tumours }\end{array}$ \\
\hline Sieri et al. (27) & $\begin{array}{l}\text { Dietary GI, GL, and the risk } \\
\text { of breast cancer in an Italian } \\
\text { prospective cohort study }\end{array}$ & Cohort & $\begin{array}{l}\text { High GI and GL vs } \\
\text { low GI and GL }\end{array}$ & $\begin{array}{l}\text { GL and GI are associated } \\
\text { with the risk of breast cance } \\
\text { in women }\end{array}$ \\
\hline Stattin et al. (28) & $\begin{array}{l}\text { Prospective study of } \\
\text { hyperglycemia and cancer risk }\end{array}$ & Cohort & $\begin{array}{l}\text { FBS and BS of the } \\
\text { top quartile versus } \\
\text { the bottom quartile }\end{array}$ & $\begin{array}{l}\text { Hyperglycemia was } \\
\text { associated with cancer risk }\end{array}$ \\
\hline $\begin{array}{l}\text { Tan-Shalaby } \\
\text { et al. (29) }\end{array}$ & $\begin{array}{l}\text { KD in advanced cancer: A pilot } \\
\text { feasibility and safety trial in the } \\
\text { veterans affairs cancer patient } \\
\text { population }\end{array}$ & $\mathrm{CT}$ & $\begin{array}{l}20 \mathrm{~g}-40 \mathrm{~g} \text { of } \\
\text { carbohydrates daily } \\
\text { for } 16 \text { weeks }\end{array}$ & $\begin{array}{l}\text { The modified Atkins diet is } \\
\text { safe and a practical approach } \\
\text { to prevent cancer progression } \\
\text { and helps to maintain the } \\
\text { quality of life }\end{array}$ \\
\hline Shukla et al. (30) & $\begin{array}{l}\text { Metabolic reprogramming } \\
\text { induced by ketone bodies } \\
\text { diminishes pancreatic cancer } \\
\text { cachexia }\end{array}$ & Experimental & Normal diet vs KD & $\begin{array}{l}\text { KD reduced tumour growth } \\
\text { and inhibited body weight } \\
\text { loss }\end{array}$ \\
\hline Allen et al. (31) & $\begin{array}{l}\text { KD enhance oxidative stress and } \\
\text { radio-chemo-therapy responses in } \\
\text { lung cancer xenografts }\end{array}$ & Experimental & Standard diet vs KD & $\begin{array}{l}\text { KD enhances radio-chemo- } \\
\text { therapy responses in lung } \\
\text { cancer xenografts by } \\
\text { mechanism that may involve } \\
\text { increased oxidative stress }\end{array}$ \\
\hline Kim et al. (32) & $\begin{array}{l}\text { Carbohydrate restriction and } \\
\text { lactate transporter inhibition in a } \\
\text { mouse xenograft model of human } \\
\text { PCa }\end{array}$ & Experimental & WD vs KD & $\begin{array}{l}\text { Differences in tumour } \\
\text { volumes were observed only } \\
\text { in comparisons between mice } \\
\text { fed a KD and mice fed a WD }\end{array}$ \\
\hline Otto et al. (33) & $\begin{array}{l}\text { Growth of human gastric cancer } \\
\text { cells in nude mice is delayed by a } \\
\text { KD supplemented with omega- } 3 \\
\text { fatty acids and MCT }\end{array}$ & Experimental & Standard diet vs KD & $\begin{array}{l}\text { An unrestricted KD enriched } \\
\text { with omega- } 3 \text { fatty acids and } \\
\text { MCT delayed tumour growth } \\
\text { in a mouse xenograft model }\end{array}$ \\
\hline $\begin{array}{l}\text { Morscher } \\
\text { et al. (34) }\end{array}$ & $\begin{array}{l}\text { Inhibition of neuroblastoma } \\
\text { tumour growth by } \mathrm{KD} \text { and/or } \\
\text { calorie restriction in a CD1-Nu } \\
\text { mouse model }\end{array}$ & Experimental & Standard diet vs KD & $\begin{array}{l}\text { KD reduced neuroblastoma } \\
\text { tumour growth }\end{array}$ \\
\hline Poff et al. (35) & $\begin{array}{l}\text { The KD and hyperbaric oxygen } \\
\text { therapy prolong survival in mice } \\
\text { with systemic metastatic cancer }\end{array}$ & Experimental & Standard diet vs KD & $\begin{array}{l}\mathrm{KD} \text { produced anti-cance } \\
\text { effects in metastatic cancer }\end{array}$ \\
\hline Caso et al. (36) & $\begin{array}{l}\text { The effect of carbohydrate } \\
\text { restriction on PCa tumour growth } \\
\text { in a castrate mouse xenograft } \\
\text { model }\end{array}$ & Experimental & WD vs KD & $\begin{array}{l}\text { Carbohydrate restriction } \\
\text { provided a benefit to } \\
\text { slowing PCa tumour growth } \\
\text { compared to a KD in mice }\end{array}$ \\
\hline $\begin{array}{l}\text { Abdelwahab } \\
\text { et al. (37) }\end{array}$ & $\begin{array}{l}\text { The KD is an effective adjuvant to } \\
\text { radiation therapy for the treatment } \\
\text { of malignant glioma }\end{array}$ & Experimental & Standard diet vs KD & $\begin{array}{l}\mathrm{KD} \text { significantly enhanced } \\
\text { the anti-tumour effect o } \\
\text { radiation }\end{array}$ \\
\hline
\end{tabular}


Review Article | Dietary carbohydrates, FTO gene and the risk of cancer

Table 1. (continued)

\begin{tabular}{|c|c|c|c|c|}
\hline Reference & Title & Study design & $\begin{array}{l}\text { Examined } \\
\text { components }\end{array}$ & Main finding(s) \\
\hline Caso et al. (36) & $\begin{array}{l}\text { The effects of varying dietary } \\
\text { carbohydrate and fat content } \\
\text { on survival in a murine LNCaP } \\
\text { prostate cancer xenograft model }\end{array}$ & Experimental & $\begin{array}{l}\text { Moderate } \\
\text { carbohydrate diet } \\
\text { vs KD }\end{array}$ & $\begin{array}{l}\text { Carbohydrate restriction } \\
\text { improved the survival rate in } \\
\text { PCa in humans }\end{array}$ \\
\hline Hao et al. (39) & $\begin{array}{l}\text { Growth of human colon cancer } \\
\text { cells in nude mice is delayed by } \\
\text { KD with or without omega- } 3 \text { fatty } \\
\text { acids and MCT }\end{array}$ & Experimental & Standard diet vs KD & $\begin{array}{l}\text { An unrestricted KD delayed } \\
\text { tumour growth in a mouse } \\
\text { xenograft model }\end{array}$ \\
\hline \multicolumn{5}{|c|}{ Dietary carbohydrates and the FTO gene } \\
\hline $\begin{array}{l}\text { Gholamalizadeh } \\
\text { et al. (51) }\end{array}$ & $\begin{array}{l}\text { Macronutrients and the } \\
\text { FTO gene expression in } \\
\text { hypothalamus; a systematic } \\
\text { review of experimental studies }\end{array}$ & $\begin{array}{l}\text { Systematic } \\
\text { review of } \\
\text { experimental } \\
\text { studies }\end{array}$ & $\begin{array}{l}\text { The effect of dietary } \\
\text { carbohydrates } \\
\text { on the FTO gene } \\
\text { expression }\end{array}$ & $\begin{array}{l}\text { Dietary carbohydrates can } \\
\text { affect the level of FTO gene } \\
\text { expression }\end{array}$ \\
\hline $\begin{array}{l}\text { Sonestedt } \\
\text { et al. (52) }\end{array}$ & $\begin{array}{l}\text { Fat and carbohydrate intake } \\
\text { modify the association between } \\
\text { genetic variation in the FTO } \\
\text { genotype and obesity }\end{array}$ & Cross-sectional & $\begin{array}{l}\text { The impact of } \\
\text { carbohydrate intake } \\
\text { on the association } \\
\text { between FTO and } \\
\text { BMI }\end{array}$ & $\begin{array}{l}\text { The relation between FTO } \\
\text { gene polymorphisms and } \\
\text { obesity can be seen only } \\
\text { in people who have a low } \\
\text { carbohydrate intake }\end{array}$ \\
\hline Qi et al. (53) & $\begin{array}{l}\text { FTO genetic variants, dietary } \\
\text { intake, and BMI: Insights from } \\
\text { 177,330 individuals. }\end{array}$ & Cross-sectional & $\begin{array}{l}\text { The impact of } \\
\text { carbohydrate intake } \\
\text { on the association } \\
\text { between FTO and } \\
\text { BMI }\end{array}$ & $\begin{array}{l}\text { Carbohydrate intake had no } \\
\text { effect on the relationship } \\
\text { between FTO and BMI }\end{array}$ \\
\hline
\end{tabular}

Body mass index (BMI), glycemic index (GI), glycemic load (GL), fasting blood sugar (FBS), blood sugar (BS), fat mass and obesity-associated (FTO), clinical trial (CT), ketogenic diet (KD), western diet (WD), medium-chain triglycerides (MCT), prostate cancer (PCa), high-protein and moderatecarbohydrate (HPMC)

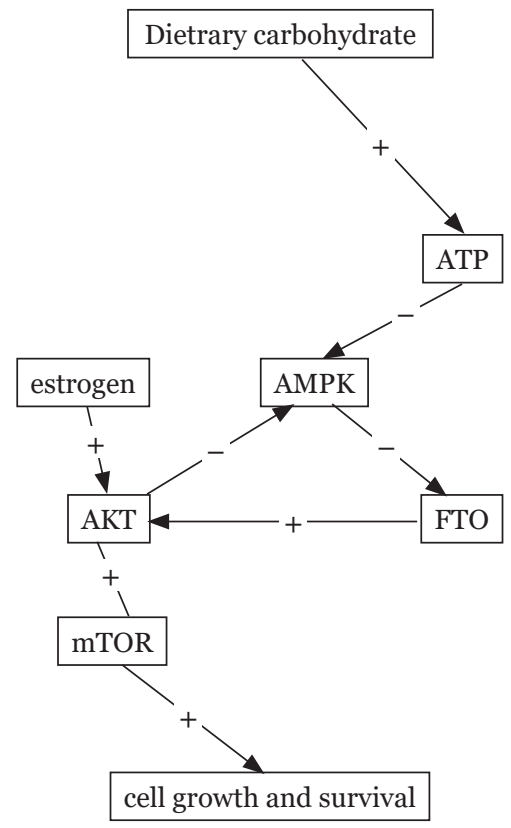

Figure 1. The effect of dietary carbohydrate on cell growth and survival through altering the FTO gene expression 


\section{Acknowledgements}

We are thankful to student research committee of Shahid Beheshti University of Medical Sciences, Tehran, Iran for their excellent supports.

\section{Conflict of Interest}

The authors contributed equally to this work. None of the authors reported a conflict of interest related to the study.

\section{Funds}

This work was supported by the Student Research Committee, Shahid Beheshti University of Medical Sciences, Tehran, Iran (grant number 13175).

\section{Authors' Contributions}

Conception and design: SD, MEA

Analysis and interpretation of the data: $\mathrm{HF}$

Drafting of the article: SD, MG

Critical revision of the article for important intellectual content: MG

Statistical expertise: AMJ

Obtaining of funding: AMJ

Data collection and assembly of data: SA, SR

\section{Correspondence}

Dr Alireza Mosavi Jarrahi

PhD (University of Texas, School of Public Health,

Houston, Texas, USA)

Department of Social Medicine, Medical School,

Shahid Beheshti University of Medical Sciences,

Tehran, Iran.

Tel: +989121145572

Fax: +98 2166428655

E-mail: rmosavi@yahoo.com

\section{References}

1. Riboli E, Hunt KJ, Slimani N, Ferrari P, Norat T, Fahey M, et al. European Prospective Investigation into Cancer and Nutrition (EPIC): study populations and data collection. Public Health Nutr. 2002;5(6b):1113-1124. https://doi. org/10.1079/PHN2OO2394
2. Béliveau R, Gingras D. Role of nutrition in preventing cancer. Canadian Fam Physician. 2007;53(11):1905-1911.

3. Birt DF, Hendrich S, Wang W. Dietary agents in cancer prevention: flavonoids and isoflavonoids. Pharmacol Ther. 2001;90(2-3):157-177. https://doi.org/10.1016/So163-7258(01)o0137-1

4. Surh YJ. Cancer chemoprevention with dietary phytochemicals. Nat Rev Cancer. 2003;3(10):768-780. https://doi.org/10.1038/ nrc1189

5. Aggarwal BB, Shishodia S. Molecular targets of dietary agents for prevention and therapy of cancer. Biochem Pharmacol. 2006;71(10):13971421. https://org.doi/10.1016/j.bcp.2006.02.009

6. Talalay P, Fahey JW. Phytochemicals from cruciferous plants protect against cancer by modulating carcinogen metabolism. $J$ Nutr. 2001;131(11):3027S-3033S.

7. Ravindran J, Prasad S, Aggarwal BB. Curcumin and cancer cells: how many ways can curry kill tumor cells selectively? AAPS J. 2009;11(3):495510. https://doi.org/10.1208/s12248-009-9128-X

8. Van Erk MJ, Teuling E, Staal YC, Huybers S, Van Bladeren PJ, Aarts JM, et al. Time-and dosedependent effects of curcumin on gene expression in human colon cancer cells. $J$ Carcinog. 2004;3(1):8. https://doi.org/10.1186/1477-3163$3-8$

9. Olsson ME, Gustavsson KE, Andersson S, Nilsson A, Duan RD. Inhibition of cancer cell proliferation in vitro by fruit and berry extracts and correlations with antioxidant levels. $J$ Agric Food Chem. 2004;52(24):7264-7271. https:// doi.org/10.1021/jfo30479p

10. Bidoli E, Talamini R, Bosetti C, Negri E, Maruzzi D, Montella M, et al. Macronutrients, fatty acids, cholesterol and prostate cancer risk. Ann Oncol. 2005;16(1):152-157. https://doi.org/10.1093/ annonc/mdio1o

11. Gatenby RA, Gillies RJ. Why do cancers have high aerobic glycolysis? Nat Rev Cancer. 2004;4(11):891-899. https://doi.org/10.1038/ $\operatorname{nrc1478}$ 
12. Zhou W, Mukherjee P, Kiebish MA, Markis WT, Mantis JG, Seyfried TN. The calorically restricted ketogenic diet, an effective alternative therapy for malignant brain cancer. Nutr Metab. 2007;4(1):5. https://doi.org/10.1186/1743-70754-5

13. Balmain A, Gray J, Ponder B. The genetics and genomics of cancer. Nat Genet. 2003;33:238244. https://doi.org/10.1038/ng1107

14. Stratton MR, Campbell PJ, Futreal PA. The cancer genome. Nature. 2009;458(7239):719-724. https://doi.org/10.1038/nature07943

15. Scully R, Livingston DM. In search of the tumoursuppressor functions of BRCA1 and BRCA2. Nature. 2000;408(6811):429-432. https://doi. org/10.1038/35044000

16. Li Y, Che M, Bhagat S, Ellis KL, Kucuk O, Doerge $\mathrm{DR}$, et al. Regulation of gene expression and inhibition of experimental prostate cancer bone metastasis by dietary genistein. Neoplasia. 2004;6(4):354-363. https://doi.org/10.1593/ neo.03478

17. Chen C, Kong AN. Dietary cancerchemopreventive compounds: from signaling and gene expression to pharmacological effects. Trends Pharmacol Sci. 2005;26(6):318-326. https://doi.org/10.1016/j.tips.2005.04.004

18. Kaklamani V, Yi N, Sadim M, Siziopikou K, Zhang $\mathrm{K}, \mathrm{Xu} \mathrm{Y}$, et al. The role of the fat mass and obesity associated gene (FTO) in breast cancer risk. BMC medical genetics. 2011;12(1):52. https://doi. org/10.1186/1471-2350-12-52

19. Frayling TM, Timpson NJ, Weedon MN, Zeggini E, Freathy RM, Lindgren CM, et al. A common variant in the FTO gene is associated with body mass index and predisposes to childhood and adult obesity. Science. 2007;316(5826):889894. https://doi.org/10.1126/science.1141634

20. Grunnet LG, Nilsson E, Ling C, Hansen T, Pedersen O, Groop L, et al. Regulation and function of FTO mRNA expression in human skeletal muscle and subcutaneous adipose tissue. Diabetes. 2009;58(10):2402-2408. https://doi. org/10.2337/dbo9-0205
21. Smemo S, Tena JJ, Kim KH, Gamazon ER, Sakabe NJ, Gómez-Marín C, et al. Obesityassociated variants within FTO form longrange functional connections with IRX 3 . Nature. 2014;507(7492):371-375. https://doi. org/10.1038/nature13138

22. Kalantari N, Mohammadi NK, Izadi P, Doaei $\mathrm{S}$, Gholamalizadeh M, Eini-Zinab $\mathrm{H}$, et al. A haplotype of three SNPs in FTO had a strong association with body composition and BMI in Iranian male adolescents. PloS One. 2018;13(4):e0195589.

23. Wylie-Rosett J, Aebersold K, Conlon B, Isasi CR, Ostrovsky NW. Health effects of low-carbohydrate diets: where should new research go? Curr Diab Rep. 2013;13(2):271-278. https://doi. org/10.1007/s11892-012-0357-5

24. Ho VW, Leung K, Hsu A, Luk B, Lai J, Shen SY, et al. A low carbohydrate, high protein diet slows tumor growth and prevents cancer initiation. Cancer Res. 2011;71(13):4484-4493. https://doi. org/10.1158/ooo8-5472.CAN-10-3973

25. Moulton CJ, Valentine RJ, Layman DK, Devkota $\mathrm{S}$, Singletary KW, Wallig MA, et al. A high protein moderate carbohydrate diet fed at discrete meals reduces early progression of $\mathrm{N}$-methyl$\mathrm{N}$-nitrosourea-induced breast tumorigenesis in rats. Nutr Metab. 2010;7(1):1. https://doi. org/10.1186/1743-7075-7-1

26. Klement RJ, Fink MK. Dietary and pharmacological modification of the insulin/IGF1 system: exploiting the full repertoire against cancer. Oncogenesis. 2016;5(2):e193. https://doi. org/10.1038/oncsis.2016.2

27. Sieri S, Pala V, Brighenti F, Pellegrini N, Muti P, Micheli A, et al. Dietary glycemic index, glycemic load, and the risk of breast cancer in an Italian prospective cohort study. Am $J$ Clin Nutr. 2007;86(4):1160-1166. https://doi.org/10.1093/ ajen/86.4.116o

28. Stattin P, Björ O, Ferrari P, Lukanova A, Lenner P, Lindahl B, et al. Prospective study of hyperglycemia and cancer risk. Diabetes Care. 2007;30(3):561-567. https://doi.org/10.2337/ dco6-0922 
29. Tan-Shalaby J, Seyfried T. Ketogenic diet in advanced cancer: a pilot feasibility and safety trial in the veterans affairs cancer patient population. J Clin Trials. 2013;3:149. https://doi. org/10.4172/2167-0870.1000149

30. Shukla SK, Gebregiworgis T, Purohit V, Chaika NV, Gunda V, Radhakrishnan P, et al. Metabolic reprogramming induced by ketone bodies diminishes pancreatic cancer cachexia. Cancer Metab. 2014;2:1-19. https:// doi.org/10.1186/2049-3002-2-18

31. Allen BG, Bhatia SK, Buatti JM, Brandt KE, Lindholm KE, Button AM, et al. Ketogenic diets enhance oxidative stress and radio-chemotherapy responses in lung cancer xenografts. Clin Cancer Res. 2013;19:3905-3913. https://doi. org/10.1158/1078-0432.CCR-12-0287

32. Kim HS, Masko EM, Poulton SL, Kennedy KM, Pizzo SV, Dewhirst MW, et al. Carbohydrate restriction and lactate transporter inhibition in a mouse xenograft model of human prostate cancer. BJU Int. 2012;110:1062-1069. https://doi. org/10.1111/j.1464-410X.2012.10971.x

33. Otto C, Kaemmerer U, Illert B, Muehling $\mathrm{B}$, Pfetzer $\mathrm{N}$, Wittig $\mathrm{R}$, et al. Growth of human gastric cancer cells in nude mice is delayed by a ketogenic diet supplemented with omega-3 fatty acids and medium-chain triglycerides. BMC Cancer. 2008;8:122. https:// doi.org/10.1186/1471-2407-8-122

34. Morscher RJ, Aminzadeh-Gohari S, Feichtinger RG, Mayr JA, Lang R, Neureiter D, et al. Inhibition of neuroblastoma tumor growth by ketogenic diet and/or calorie restriction in a CD1Nu mouse model. PLoS One. 2015;10:e0129802.s. https://doi.org/10.1371/journal.pone.0129802

35. Poff AM, Ari C, Seyfried TN, D'Agostino DP. The ketogenic diet and hyperbaric oxygen therapy prolong survival in mice with systemic metastatic cancer. PLoS One. 2013;8:e65522. https://doi. org/10.1371/journal.pone.0065522

36. Caso J, Masko EM, Ii JA, Poulton SH, Dewhirst M, Pizzo SV, et al. The effect of carbohydrate restriction on prostate cancer tumor growth in a castrate mouse xenograft model. Prostate. 2013;73:449-454. https://doi.org/10.1002/ pros. 22586
37. Abdelwahab MG, Fenton KE, Preul MC, Rho JM, Lynch A, Stafford P, et al. The ketogenic diet is an effective adjuvant to radiation therapy for the treatment of malignant glioma. PLoS One. 2012;7:e36197. https://doi.org/10.1371/journal. pone.0036197

38. Mavropoulos JC, Buschemeyer WC III, Tewari AK, Rokhfeld D, Pollak M, Zhao Y, et al. The effects of varying dietary carbohydrate and fat content on survival in a murine LNCaP prostate cancer xenograft model. Cancer Prev Res (Phila). 2009;2(6):557-565. https://doi. org/10.1158/1940-6207.CAPR-o8-0188

39. Hao GW, Chen YS, He DM, Wang HY, Wu GH, Zhang B. Growth of human colon cancer cells in nude mice is delayed by ketogenic diet with or without omega-3 fatty acids and mediumchain triglycerides. Asian Pac $J$ Cancer Prev. 2015;16:2061-8.

40. Klement RJ, Kämmerer U. Is there a role for carbohydrate restriction in the treatment and prevention of cancer? Nutr Metab. 2011;8(1):75. https://doi.org/10.1186/1743-7075-8-75

41. Chen Y, Ling L, Su G, Han M, Fan X, Xun P, et al. Effect of intermittent versus chronic calorie restriction on tumor incidence: a systematic review and meta-analysis of animal studies. Sci Rep. 2016;6. https://doi.org/10.1038/srep33739

42. Devic S. Warburg effect-a consequence or the cause of carcinogenesis? J Cancer. 2016;7(7):817. https://doi.org/10.7150/jca.14274

43. Fortin J, Mak TW. Targeting $\mathrm{PI}_{3} \mathrm{~K}$ signaling in cancer: a cautionary tale of two AKTs. Cancer Cell. 2016;29(4):429-431. https://doi. org/10.1016/j.ccell.2016.03.020

44. Geuna E, Roda D, Rafii S, Jimenez B, Capelan M, Rihawi K, et al. Complications of hyperglycaemia with $\mathrm{PI} 3 \mathrm{~K}-\mathrm{AKT}-\mathrm{mTOR}$ inhibitors in patients with advanced solid tumours on Phase I clinical trials. $\mathrm{Br} J$ Cancer. 2015;113(11):1541-1547. https://doi.org/10.1038/bjc.2015.373

45. Liu Y, Wang R, Zhang L, Li J, Lou K, Shi B. The lipid metabolism gene FTO influences breast cancer cell energy metabolism via the $\mathrm{PI}_{3} \mathrm{~K} /$ Akt signaling pathway. Oncol Lett. 2017;13(6):4685469o. https://doi.org/10.3892/ol.2017.6038 
46. Kaklamani V1, Yi N, Sadim M, Siziopikou K, Zhang $\mathrm{K}, \mathrm{Xu} \mathrm{Y}$, et al. The role of the fat mass and obesity associated gene (FTO) in breast cancer risk. BMC Med Genet. 2011;12:52. https://doi. org/10.1186/1471-2350-12-52

47. Badakhanian M, Najafi R. The IRX3 gene; the missing link between the FTO gene and obesity. Asian Pac J Cancer Biol. 2016;1(2):25-27. https://doi.org/10.22034/APJCB.2016.1.2.25

48. Huang $\mathrm{X}$, Zhao J, Yang M, Li M, Zheng J. Association between FTO gene polymorphism (rs9939609 T/A) and cancer risk: a meta-analysis. Eur J Cancer Care. 2017;26(5): e12464. https:// doi.org/10.1111/ecc.12464

49. Yang B, Thrift AP, Figueiredo JC, Jenkins MA, Schumacher FR, Conti DV, et al. Common variants in the obesity-associated genes FTO and $\mathrm{MC} 4 \mathrm{R}$ are not associated with risk of colorectal cancer. Cancer Epidemiol. 2016;44:1-4. https:// doi.org/10.1016/j.canep.2016.07.003

50. Jafari-Nedooshan J, Kargar S, Neamatzadeh H, Haghighi F, Seddighi N. Lack of Association of the Fat Mass and Obesity Associated (FTO) gene rs9939609 polymorphism with breast cancer risk: a systematic review and meta-analysis based on case-control studies. Asian Pac $J$ Cancer Prev. 2017;18(4):1031-1037. https://doi. org/10.22034/APJCP.2017.18.4.1031

51. Gholamalizadeh M, Doaei S, Akbari M, Rezaei $\mathrm{S}$, Jarrahi A. Influence of fat mass-and obesityassociated genotype, body mass index, and dietary intake on effects of Iroquois-related Homeobox 3 gene on body weight. Chin Med J. 2018;131(17):2112-2113.
52. Sonestedt E, Roos C, Gullberg B, Ericson U, Wirfalt E, Orho-Melander M. Fat and carbohydrate intake modify the association between genetic variation in the FTO genotype and obesity. Am J Clin Nutr. 2009;90(5):14181425. https://doi.org/10.3945/ajcn.2009.27958

53. Qi Q, Kilpeläinen TO, Downer MK, Tanaka T, Smith CE, Sluijs I, et al. FTO genetic variants, dietary intake and body mass index: insights from 177330 individuals. Hum Mol Genet. 2014;23(25):6961-6972. https://doi. org/10.1093/hmg/ddu411

54. Liu Y, Wang R, Zhang L, Li J, Lou K, Shi B. The lipid metabolism gene FTO influences breast cancer cell energy metabolism via the $\mathrm{PI}_{3} \mathrm{~K} / \mathrm{Akt}$ signaling pathway. Oncol Lett. 2017;13(6):46854690. https://doi.org/10.3892/ol.2017.6038

55. Jiao Y, Zhang J, Lu L, Xu J, Qin L. The FTO gene regulates the proliferation and differentiation of pre-adipocytes in vitro. Nutrients. 2016;8(2):102. https://doi.org/10.3390/nu8020102

56. Zhu Y, Shen J, Gao L, Feng Y. Estrogen promotes fat mass and obesity-associated protein nuclear localization and enhances endometrial cancer cell proliferation via the mTOR signaling pathway. Oncol Rep. 2016;35(4):2391-2397. https://doi. org/10.3892/or.2016.4613 